\title{
1 Ligand-independent modulation of GIPR signaling by splice variants
}

2 Kaini Hang ${ }^{1,2,3,4, \uparrow}$, Lijun Shao ${ }^{2,3, \uparrow}$, Qingtong Zhou ${ }^{5}$, Fenghui Zhao ${ }^{6}$, Antao Dai ${ }^{6}$,

3 Xiaoqing Cai ${ }^{6}$, Raymond C. Stevens ${ }^{1,2}$, Dehua Yang $3,6,7,8, *$, Ming-Wei Wang ${ }^{2,3,5,6,7,8, *}$

$4 \quad{ }^{1}$ iHuman Institute, ShanghaiTech University, Shanghai 201210, China.

$5 \quad{ }^{2}$ School of Life Science and Technology, ShanghaiTech University, Shanghai 201210,

6 China

$7 \quad{ }^{3}$ University of Chinese Academy of Sciences, Beijing 100049, China.

$8{ }^{4}$ CAS Center for Excellence in Molecular Cell Science, Shanghai Institute of 9 Biochemistry and Cell Biology, Shanghai 200031, China.

${ }^{5}$ Department of Pharmacology, School of Basic Medical Sciences, Fudan University, Shanghai 200032, China.

${ }^{6}$ The National Center for Drug Screening, Shanghai Institute of Materia Medica, Chinese Academy of Sciences, Shanghai 201203, China.

${ }^{7}$ The CAS Key Laboratory of Receptor Research, Shanghai Institute of Materia Medica, Chinese Academy of Sciences, Shanghai 201203, China. (M.-W.W.)

\section{Abstract}

Glucose-dependent insulinotropic polypeptide receptor (GIPR) is a potential drug target for metabolic disorders. It works with glucagon-like peptide-1 receptor (GLP-1R) and glucagon receptor (GCGR) in humans to maintain glucose homeostasis. Unlike the other two receptors, GIPR has at least 7 reported (EMBL-EBI, 2022; NCBI, 2022a, 2022b) splice variants (SVs) with previously undefined functions. To explore their roles in endogenous peptide mediated GIPR signaling, we investigated the outcome of coexpressing each of the four SVs in question with GIPR in terms of ligand binding, cAMP accumulation, Gs activation, $\beta$-arrestin recruitment and cell surface localization. The effects of these SVs on intracellular cAMP responses modulated by receptor 
activity-modifying proteins (RAMPs) were also studied. It was found that while SVs of GIPR neither bound to the hormone nor affected its signal transduction per se, they differentially regulated GIPR-mediated cAMP and $\beta$-arrestin responses. Specifically, SV1 and SV4 were preferable to $\mathrm{G}_{\mathrm{s}}$ signaling, SV3 was biased towards $\beta$-arrestin recruitment, whereas SV2 was inactive on both pathways. In the presence of RAMPs, only SV1 and SV4 synergized the repressive action of RAMP3 on GIP-elicited cAMP production. The results suggest a new form of signal bias that is constitutive and ligandindependent, thereby expanding our knowledge of biased signaling beyond pharmacological manipulation (i.e., ligand specific) as well as constitutive and liganddependent (e.g., SV1 of the growth hormone-releasing hormone receptor).

\section{Introduction}

G protein-coupled receptors (GPCRs) represent the largest family of membrane proteins that are universally expressed in human tissues (Pavlos \& Friedman, 2017). They can recognize a diverse range of extracellular ligands and transduce signals to intracellular coupling partners, thereby governing crucial physiological functions (Strange, 2008). GPCR-mediated signaling and pharmacological activities could be profoundly affected by alternative splicing, leading to functional diversity (Furness, Wootten, Christopoulos, \& Sexton, 2012; Marti-Solano et al., 2020).

Splice variants (SVs) have been observed in many GPCRs, in which sequence variations may include $\mathrm{N}$ terminus truncation or/and substitution, $\mathrm{C}$ terminus truncation or/and substitution, intracellular/extracellular loop differences, severe truncation leading to variants with less than 7 transmembrane domains (TMDs) or soluble variants (Markovic \& Challiss, 2009). In general, $\mathrm{N}$ terminus variations impair ligand binding properties, such as corticotropin releasing hormone receptor 1 (CRH1R) and 2 (CRHR2) (Evans \& Seasholtz, 2009), calcitonin receptor (CTR) (Nag, Sultana, Kato, \& Hirose, 2007) and parathyroid hormone 1 receptor (PTH1R) (Joun et al., 1997), while C terminus variations show altered signaling or protein interactions, such as metabotropic glutamate receptors (mGluRs) (Cai, Schools, \& Kimelberg, 2000), $\mu$-opioid receptor (MOR) (Lu et al., 2015) and 5-hydroxytryptamine (5-HT) receptors (Coupar, Desmond, \& Irving, 2007). Intracellular loop (ICL) differences affect G protein coupling 
preference and extracellular loop (ECL) differences alter ligand specificity and binding kinetics, as illustrated by pituitary adenylate cyclase-activating polypeptide (PACAP) type 1 receptor (PAC1R) (McCulloch et al., 2001) and D3 dopamine receptor (D3R) (Karpa, Lin, Kabbani, \& Levenson, 2000; Richtand, 2006), respectively. Variants with less than 7 TMDs caused by severe $\mathrm{N}$ terminus truncation exhibit negative effect on wild-type (WT) receptor signaling (Markovic \& Challiss, 2009).

Glucose-dependent insulinotropic polypeptide receptor (GIPR) belongs to class B1 subfamily of GPCRs and is present in pancreatic cells, adipose tissues and osteoblasts. Upon GIP stimulation, it regulates insulin secretion, fat accumulation and bone formation by increasing intracellular adenosine 3,5-cyclic monophosphate (cAMP) levels (Campbell, 2021; Yabe \& Seino, 2011; Yue \& Lam, 2019). GIPR is reported to have a truncated SV showing a dominant negative effect on the translocation of WT GIPR from the endoplasmic reticulum (ER) to the cell surface, leading to a decreased activity (Harada et al., 2008). However, the functionalities of GIPR SVs remain to be defined.

In this study, we constructed and expressed four representative GIPR SVs to elaborate their biological properties on GIPR-mediated cAMP accumulation and $\beta$ arrestin recruitment. They were selected based on expression levels and splicing modes: SV1, SV2, SV3 and SV4 with residue lengths of 419, 430, 405 and 265, respectively (Figure 1). SV1 has a truncated C terminus and a 20 amino acid substitution. SV2 lacks the sequence of residues 58-93 at the $\mathrm{N}$ terminus. SV3 has a replaced $\mathrm{N}$ terminus of residues 1-93. SV4 only has 3 TMDs.

\section{Results}

\section{Splice variants neither bind nor affect GIP-induced cAMP response}

We first expressed GIPR and four SVs separately in HEK293T cells to investigate their ability to bind GIP $1_{-42}$ and elicit cAMP accumulation and $\beta$-arrestin recruitment. Figure 2 shows that none of the SVs displayed any ligand-binding and signaling properties, whereas the WT receptor was highly active in each parameter analyzed.

\section{Splice variants differentially modulate GIPR-mediated signaling}

Since SVs are usually express in cells and tissues where GIPR are present (GTEx, 2022; 
Harada et al., 2008), we co-transfected GIPR with each SV in order to study if they influence the signaling profile of the WT receptor. While the binding affinity of GIP 1 42 to the cognate receptor were significantly reduced by $0.44,0.54,0.50$ and 0.74 folds for SV1, SV2, SV3 and SV4, respectively (Figure 3A and Table 1), cAMP and $\beta$ arrestin responses at GIPR were differentially and negatively modulated. Both SV1 and SV4 decreased cAMP signaling but the effect of SV4 was nearly 5-fold stronger than that of SV1, SV2 and SV3 were inactive (Figure 3B and Table 1). Although SV1, SV3 and SV4 decreased the $E_{\max }$ values of $\beta$-arrestin 2 recruitment by $0.59,0.49$ and $0.42-$ folds, respectively, and SV2 remained inactive (Figure 3D and Table 1), none of them influenced on $\beta$-arrestin 1 recruitment (Figure 3C).

\section{GIPR and splice variants are co-localized on the membrane}

GIPR and SVs could be localized either on the membrane or the cytoplasm of transfected HEK293T cells (Figure 4A and 4B). Figure 4C illustrates that GIPR, SV1 and SV4 were co-expressed mostly on the cell surface, whereas SV2 and SV3 only exhibited a partial membrane co-localization. Upon co-transfection with GIPR, most of SV3 were translocated to the membrane ( $3^{\text {rd }}$ panel of Figure $\left.4 \mathrm{C}\right)$, but SV2 remained in the cytoplasm along with redistributed GIPR $\left(2^{\text {nd }}\right.$ panel of Figure $\left.4 C\right)$, consistent with the silent role of SV2 observed.

\section{Synergistic effect exerted by splice variants and RAMP3}

Receptor activity-modifying protein 3 (RAMP3) was reported to reduce GIP $_{1-42}$ induced cAMP accumulation at GIPR as opposed to RAMPs 1 and 2 that showed no effect (Harris, Mackie, Pawlak, Carvalho, \& Ladds, 2021; Shao et al., 2021). After coexpression of individual SVs with GIPR and each RAMP, no alteration was noted with RAMP1 and RAMP2 (Figure 5A and 5B), but the suppression of GIPR-mediated cAMP production by RAMP3 was moderately augmented by SV1 and SV4 (with EC 50 increased by 0.54 and 0.96-fold, respectively) (Figure 5C and Table 2).

\section{SV1 and SV4 are repressive on $G_{s}$ activation}

We also studied the effect of SVs on $\mathrm{G}_{\mathrm{s}}$ protein coupling by GIPR. Gs activation was assessed using a split luciferase NanoBiT G protein sensor. Individually expressing SVs showed no ability to active $\mathrm{G}_{\mathrm{s}}$ (Figure 6A), consistent with their lack of cAMP signaling 
(Figure 2B). SV1 and SV4 markedly impaired $\mathrm{G}_{\mathrm{s}}$ coupling with 4.89- and 2.68-fold increased $\mathrm{EC}_{50}$ values, respectively (Figure $6 \mathrm{~B}$ and Table 1). Although the $\mathrm{P}$ values of pEC50 for SV1 and SV4 were greater than 0.05 probably due to inherent assay variations, the difference between their $\mathrm{EC}_{50}$ and that of GIPR alone was statistically significant (Figure $6 \mathrm{C}$ and $\mathrm{D}$ ), thus in line with their repressive action on cAMP accumulation (Figure 3B).

\section{Diminished interaction between splice variants and signaling partners}

As shown in Figure 7A-C, the helix $8(\mathrm{H} 8)$ of SV1 adopted a distinct conformation from that of GIPR during molecular dynamics (MD) simulations, bent upwards and moved away from $G \beta$, thereby resulting in a reduced receptor-G $\beta$ interface area. Of note, the specific residue in GIPR H8 (such as R405) stabilized the G $\beta$ binding, which was absent in SV1, consistent with its role in $\mathrm{G}_{\mathrm{s}}$-mediated signaling. Compared to GIPR, obvious differences in peptide-binding and $\beta$-arrestin 1 interface were observed for SV3 (Figure 7D-F). By replacing the GIPR extracellular domain (ECD) with a smaller domain (61 fewer residues), SV3 reorganized its extracellular half including ECL1 to accommodate peptide binding with a smaller peptide-receptor interface (from $3,280 \AA^{2}$ in the last $500 \mathrm{~ns}$ MD simulation of GIPR to $2,826 \AA^{2}$ in that of SV1). As far as the intracellular half is concerned, $\beta$-arrestin 1 inserted deeper to the SV3 core compared with that of GIPR (Figure 7E). These different structural and dynamics features between SV3 and GIPR highlight their distinct signaling properties.

\section{Discussion}

GIP, glucagon-like peptide-1 (GLP-1) and glucagon (GCG) together play a pivotal role in glucose homeostasis mediated via their respective receptors (Cho, Merchant, \& Kieffer, 2012; Sekar, Singh, Arokiaraj, \& Chow, 2016). GCG increases the release of glucose, while GIP and GLP-1R work synergistically to cause postprandial insulin secretion, regulate glucagon secretion, stimulate $\beta$ cell proliferation and protect it from apoptosis (Alexiadou, Anyiam, \& Tan, 2019; Estall \& Drucker, 2006; Hansotia \& Drucker, 2005; Seino, Fukushima, \& Yabe, 2010; Skow, Bergmann, \& Knop, 2016). Of note is that GIP promotes the release of both insulin and glucagon (Gasbjerg et al., 
2018) thereby modulating the action of GLP-1 and GCG on sugar metabolism, probably involving some SVs of GIPR.

A common feature of the SVs examined is that they neither bind the native ligand, GIP $1-42$, nor elicit signal transduction. When co-expressed with WT GIPR, all of them reduced peptide binding in a similar manner while displaying distinct signaling profiles (Figure 8). Both SV1 and SV4 decreased GIPR-mediated cAMP and $\beta$-arrestin 2 responses; SV3 selectively suppressed $\beta$-arrestin 2 recruitment, and SV2 had no effect on the two signaling events, but diminished GIPR presence in the membrane. While SV1 (SV4 to less extent) may have the preference for activating the $\mathrm{G}_{\mathrm{s}}$ pathway, SV3 obviously is biased towards $\beta$-arrestin 2 recruitment.

Consistent with previous findings showing that SVs are capable of altering signaling profiles compared to WT receptors (Kochman, 2014; Maggio et al., 2016), our data suggest a constitutive biased mechanism different from signal bias caused by various ligands. For example, SVs of the C-X-C chemokine receptor 3 (CXCR3) could activate different signaling pathways through biased agonism (Berchiche \& Sakmar, 2016), and SV1 of the growth hormone-releasing hormone receptor (GHRHR) preferentially transduces signals via $\beta$-arrestins while GHRHR predominantly activates Gs proteins (Cong et al., 2021). However, unlike other GPCR SVs, that of GIPR are incapacitated in terms of ligand-binding and signal transduction per se, but negatively affect that of the WT receptor in a ligand-independent and signaling biased manner.

Bidirectional regulation of carbohydrate levels by $\mathrm{GIP}_{1-42}$ is essential to the maintenance of glucose homeostasis, although this hinders the development of therapeutic agents targeting GIPR (Killion et al., 2018). It seems that such a unique modulation of gut hormone actions is finely tuned by SVs with differentiated functionalities: the repression of cAMP response imposed by RAMP3 could be strengthened by SV1 and SV4, whereas $\beta$-arrestin 2 signaling is solely modified by SV3. Unlike the other three SVs, SV2 appears as a sequester that redistributes the membrane GIPR to the cytoplasm, evidenced by immunofluorescence staining when 
177 both WT GIPR and SV2 are co-expressed. Whether this constitutes a shutdown

178 mechanism for GIPR function remains to be explored.

179 The roles of SVs in GIPR functioning are unique not only because they are of

180 repressive nature but also due to their synergistic actions with RAMP3 that itself is a

181 negative regulator of most members of the glucagon receptor subfamily of class B1

182 GPCRs (Shao et al., 2021). It remains elusive if the above described phenomenon

183 constitutes a "doubly insured" mechanism for signal modulation in order to fine tune

184 the action of $\mathrm{GIP}_{1-42}$. Clearly both in-depth structural and biochemical studies are

185 required to solve the puzzle. 
Materials and Methods

188 Key resource table

\begin{tabular}{|c|c|c|c|c|}
\hline $\begin{array}{l}\text { Reagent type } \\
\text { (species) or } \\
\text { resource }\end{array}$ & Designation & Source or reference & Identifier & $\begin{array}{l}\text { Additional } \\
\text { information }\end{array}$ \\
\hline Transcript ID & WT GIPR & ENSEMBL & $\begin{array}{l}\text { ENST00000 } \\
590918.6\end{array}$ & \\
\hline Transcript ID & Splice variant 1 & ENSEMBL & $\begin{array}{l}\text { ENST00000 } \\
263281.7\end{array}$ & \\
\hline Transcript ID & Splice variant 2 & ENSEMBL & $\begin{array}{l}\text { ENST00000 } \\
304207.12\end{array}$ & \\
\hline Transcript ID & Splice variant 3 & ENSEMBL & $\begin{array}{l}\text { ENST00000 } \\
652180.1\end{array}$ & \\
\hline Transcript ID & Splice variant 4 & ENSEMBL & $\begin{array}{l}\text { ENST00000 } \\
585889.1\end{array}$ & \\
\hline $\begin{array}{l}\text { Cell line (Homo } \\
\text { sapiens) }\end{array}$ & HEK293T & ATCC & $\begin{array}{l}\text { Cat. No.: } \\
\text { CRL-3216 }\end{array}$ & \\
\hline $\begin{array}{l}\text { Cell line } \\
\text { (hamster) }\end{array}$ & CHO-K1 & ATCC & $\begin{array}{l}\text { Cat. No.: } \\
\text { CCL-61 }\end{array}$ & \\
\hline $\begin{array}{l}\text { Recombinant } \\
\text { DNA reagent }\end{array}$ & $\begin{array}{l}\text { pcDNA3.1-GIPR (WT } \\
\text { and splice variants) }\end{array}$ & This paper & $\mathrm{N} / \mathrm{A}$ & \\
\hline $\begin{array}{l}\text { Recombinant } \\
\text { DNA reagent }\end{array}$ & $\begin{array}{l}\text { pcDNA3.1-GIPR } \\
\text { (WT)-HA }\end{array}$ & $\begin{array}{l}\text { doi: } \\
\text { 10.1016/j.bcp.2020.1 } \\
14001\end{array}$ & N/A & \\
\hline $\begin{array}{l}\text { Recombinant } \\
\text { DNA reagent }\end{array}$ & $\begin{array}{l}\text { pcDNA3.1-GIPR } \\
\text { (splice variants) -FLAG }\end{array}$ & This paper & N/A & \\
\hline $\begin{array}{l}\text { Recombinant } \\
\text { DNA reagent }\end{array}$ & $\begin{array}{l}\text { pcDNA3.1-GIPR (WT } \\
\text { and splice variants)- }\end{array}$ & This paper & N/A & \\
\hline
\end{tabular}




\begin{tabular}{|c|c|c|c|c|}
\hline & $\begin{array}{l}\text { Rluc8 (Renilla } \\
\text { luciferase 8) }\end{array}$ & & & \\
\hline $\begin{array}{l}\text { Recombinant } \\
\text { DNA reagent }\end{array}$ & $\begin{array}{l}\text { Venus- } \beta \text {-arrestins } 1 \text { and } \\
2\end{array}$ & $\begin{array}{l}\text { doi: } \\
\text { 10.1016/j.bcp.2020.1 } \\
14001\end{array}$ & N/A & \\
\hline $\begin{array}{l}\text { Recombinant } \\
\text { DNA reagent }\end{array}$ & pcDNA3-RAMP3 & $\begin{array}{l}\text { doi: } \\
\text { 10.1016/j.apsb.2021. } \\
07.028\end{array}$ & N/A & \\
\hline $\begin{array}{l}\text { Peptide, } \\
\text { recombinant } \\
\text { protein }\end{array}$ & $\mathrm{GIP}_{1-42}$ & GenScript & $\mathrm{N} / \mathrm{A}$ & \\
\hline $\begin{array}{l}\text { Chemical } \\
\text { compound, drug }\end{array}$ & $\begin{array}{l}\text { Bovine serum albumin } \\
\text { (BSA) }\end{array}$ & ABCONE & $\begin{array}{l}\text { Cat. No.: } \\
\text { A23088- } \\
100 \mathrm{G}\end{array}$ & \\
\hline $\begin{array}{l}\text { Chemical } \\
\text { compound, drug }\end{array}$ & $\begin{array}{l}\text { 3-Isobutylene-1- } \\
\text { methylxanthine } \\
\text { (IBMX) }\end{array}$ & ABCONE & $\begin{array}{l}\text { Cat. No.: } \\
\text { I72182- } \\
250 \mathrm{MG}\end{array}$ & \\
\hline $\begin{array}{l}\text { Chemical } \\
\text { compound, drug }\end{array}$ & $\begin{array}{l}\text { Fetal bovine serum } \\
\text { (FBS) }\end{array}$ & Gibco & $\begin{array}{l}\text { Cat. No.: } \\
\text { 10099-141 }\end{array}$ & \\
\hline $\begin{array}{l}\text { Chemical } \\
\text { compound, drug }\end{array}$ & $\begin{array}{l}\text { Dulbecco's modified } \\
\text { Eagle's medium } \\
\text { (DMEM) }\end{array}$ & Gibco & $\begin{array}{l}\text { Cat. No.: } \\
\text { 12430-054 }\end{array}$ & \\
\hline $\begin{array}{l}\text { Chemical } \\
\text { compound, drug }\end{array}$ & $\begin{array}{l}\text { Ham's F-12 nutrient } \\
\text { mix (F12) }\end{array}$ & Gibco & $\begin{array}{l}\text { Cat. No.: } \\
\text { C11765500 }\end{array}$ & \\
\hline $\begin{array}{l}\text { Chemical } \\
\text { compound, drug }\end{array}$ & $\begin{array}{l}\text { Hanks' Balanced Salt } \\
\text { solution (HBSS) }\end{array}$ & Gibco & $\begin{array}{l}\text { Cat. No.: } \\
\text { C14175500 }\end{array}$ & \\
\hline $\begin{array}{l}\text { Chemical } \\
\text { compound, drug }\end{array}$ & HEPES & Gibco & $\begin{array}{l}\text { Cat. No.: } \\
\text { 15630-080 }\end{array}$ & \\
\hline
\end{tabular}




\begin{tabular}{|c|c|c|c|c|}
\hline $\begin{array}{l}\text { Chemical } \\
\text { compound, drug }\end{array}$ & Sodium pyruvate & Gibco & $\begin{array}{l}\text { Cat. No.: } \\
\text { 11360-0'70 }\end{array}$ & \\
\hline $\begin{array}{l}\text { Chemical } \\
\text { compound, drug }\end{array}$ & $\begin{array}{l}\text { Lipofectamine } 2000 \\
\text { transfection reagent }\end{array}$ & Invitrogen & $\begin{array}{l}\text { Cat. No.: } \\
11668-019\end{array}$ & \\
\hline $\begin{array}{l}\text { Chemical } \\
\text { compound, drug }\end{array}$ & ${ }^{125} \mathrm{I}-\mathrm{GIP}$ & PerkinElmer & $\begin{array}{l}\text { Cat. No.: } \\
\text { NEX40201 } \\
\text { 0UC }\end{array}$ & \\
\hline $\begin{array}{l}\text { Chemical } \\
\text { compound, drug }\end{array}$ & Coelenterazine $\mathrm{H}$ & Yeasen Biotech & $\begin{array}{l}\text { Cat. No.: } \\
\text { 40906ES02 }\end{array}$ & \\
\hline Antibody & $\begin{array}{l}\text { Anti-FLAG primary } \\
\text { antibody }\end{array}$ & Sigma-Aldrich & $\begin{array}{l}\text { Cat. No.: } \\
\text { F3165 }\end{array}$ & \\
\hline Antibody & $\begin{array}{l}\text { Anti-HA primary } \\
\text { antibody }\end{array}$ & $\begin{array}{l}\text { Cell Signaling } \\
\text { Technology }\end{array}$ & $\begin{array}{l}\text { Cat. No.: } \\
3724 \mathrm{~S}\end{array}$ & \\
\hline Antibody & $\begin{array}{l}\text { Anti-mouse Alexa } \\
\text { Fluor } 647 \text { conjugated } \\
\text { secondary antibody }\end{array}$ & Invitrogen & $\begin{array}{l}\text { Cat. No.: } \\
\text { A31571 }\end{array}$ & \\
\hline Antibody & $\begin{array}{l}\text { Anti-rabbit Alexa Fluor } \\
488 \text { conjugated } \\
\text { secondary antibody }\end{array}$ & Invitrogen & $\begin{array}{l}\text { Cat. No.: } \\
\text { A21206 }\end{array}$ & \\
\hline $\begin{array}{l}\text { Commercial } \\
\text { assay, kit }\end{array}$ & $\begin{array}{l}\text { LANCE Ultra cAMP } \\
\text { kit }\end{array}$ & PerkinElmer & $\begin{array}{l}\text { Cat. No.: } \\
2675984\end{array}$ & \\
\hline $\begin{array}{l}\text { Software, } \\
\text { algorithm }\end{array}$ & GraphPad Prism v8.4 & GraphPad Software & $\mathrm{N} / \mathrm{A}$ & $\begin{array}{l}\text { https://www.graph } \\
\text { pad.com/ }\end{array}$ \\
\hline $\begin{array}{l}\text { Software, } \\
\text { algorithm }\end{array}$ & FreeSASA & $\begin{array}{l}\text { doi: } \\
\text { 10.12688/f1000researc } \\
\text { h.7931.1 }\end{array}$ & N/A & $\begin{array}{l}\text { http://freesasa.githu } \\
\text { b.io/ }\end{array}$ \\
\hline $\begin{array}{l}\text { Software, } \\
\text { algorithm }\end{array}$ & Gromacs 2020.1 & $\begin{array}{l}\text { doi: } \\
10.1016 / \text { j.softx.2015 } \\
.06 .001\end{array}$ & $\mathrm{~N} / \mathrm{A}$ & $\begin{array}{l}\text { https://manual.gro } \\
\text { macs.org/2020.1/do } \\
\text { wnload.html }\end{array}$ \\
\hline
\end{tabular}




\begin{tabular}{|l|l|l|l|l|}
\hline $\begin{array}{l}\text { Software, } \\
\text { algorithm }\end{array}$ & $\begin{array}{l}\text { Protein Preparation } \\
\text { Wizard }\end{array}$ & Schrödinger & N/A & $\begin{array}{l}\text { https://www.schrod } \\
\text { inger.com/products } \\
\text { /protein- } \\
\text { preparation-wizard }\end{array}$ \\
\hline $\begin{array}{l}\text { Software, } \\
\text { algorithm }\end{array}$ & $\begin{array}{l}\text { CHARMM-GUI } \\
\text { Membrane } \\
\text { Builder v3.6 }\end{array}$ & $\begin{array}{l}\text { doi: } \\
10.1002 / \text { jcc.23702 }\end{array}$ & N/A & https:/charmm- \\
Software, \\
algorithm
\end{tabular}$\quad$\begin{tabular}{l} 
CHARMM36-CAMP \\
\hline $\begin{array}{l}\text { Software, } \\
\text { algorithm }\end{array}$
\end{tabular}

\section{Cell culture}

HEK293T cells were maintained in DMEM (Gibco) supplemented with 10\% FBS (Gibco) and $100 \mathrm{mM}$ sodium pyruvate (Gibco). CHO-K1 cells were maintained in F12 (Gibco) supplemented with 10\% FBS. All cells were incubated in a humidified environment at $37{ }^{\circ} \mathrm{C}$ in $5 \% \mathrm{CO}_{2}$.

\section{Construct}

cDNAs were inserted into pcDNA3.1 vector by one-step cloning. Addition of FLAGand HA-tags to WT GIPR or SVs was carried out by site-directed mutagenesis. WT GIPR or SVs were cloned to the backbone of Rluc8 at the $\mathrm{C}$ terminus. All constructs were confirmed by DNA sequencing (GENEWIZ, Suzhou, China). To optimizing the co-transfection assays, three GIPR vs. SV ratios (1:1, 1:3 and 1:6) were tried. Since the impact of $1: 1$ on GIPR activity was hard to observe and that of $1: 3$ and 1.6 was similar, we selected 1:3 for the entire study.

203 GIP $1-42$ stimulated cAMP accumulation was measured by a LANCE Ultra cAMP kit (PerkinElmer). Cells were seeded onto 6-well cell culture plates and transiently transfected with $4 \mu \mathrm{g}$ plasmid using Lipofectamine 2000 transfection reagent 
(Invitrogen). After $24 \mathrm{~h}$ culture, the transfected cells were seeded onto 384-well microtiter plates at a density of 3,000 cells per well in HBSS (Gibco) supplemented with $5 \mathrm{mM}$ HEPES (Gibco), 0.1\% (w/v) bovine serum albumin (BSA) and $0.5 \mathrm{mM}$ IBMX (Sigma-Aldrich). The cells were stimulated with different concentrations of GIP $_{1-42}$ for 40 min at room temperature (RT). Eu and Ulight were then diluted by cAMP detection buffer and added to the plates separately to terminate the reaction. Plates were incubated at RT for $40 \mathrm{~min}$ and the fluorescence intensity measured at $620 \mathrm{~nm}$ and 650 nm by an EnVision multilabel plate reader (PerkinElmer).

\section{Whole-cell binding assay}

CHO-K1 cells were seeded at a density of 30,000 cells/well in Isoplate-96 plates (PerkinElmer). The WT GIPR or SVs were transiently transfected using Lipofectamine 2000 transfection reagent. Twenty-four hours after transfection, cells were washed twice, and incubated with blocking buffer (F12 supplemented with $33 \mathrm{mM}$ HEPES and $0.1 \% \mathrm{BSA}, \mathrm{pH} 7.4$ ) for $2 \mathrm{~h}$ at $37^{\circ} \mathrm{C}$. For homogeneous binding, cells were incubated in binding buffer with a constant concentration of ${ }^{125} \mathrm{I}-\mathrm{GIP}$ (40 pM, PerkinElmer) and increasing concentrations of unlabeled $\mathrm{GIP}_{1-42}(3.57 \mathrm{pM}$ to $1 \mu \mathrm{M})$ at RT for $3 \mathrm{~h}$. Following incubation, cells were washed three times with ice-cold PBS and lysed by addition of $50 \mu \mathrm{L}$ lysis buffer (PBS supplemented with $20 \mathrm{mM}$ Tris-HCl, 1\% Triton X100, pH 7.4). Fifty $\mu \mathrm{L}$ of scintillation cocktail (OptiPhase SuperMix, PerkinElmer) was added and the plates were subsequently counted for radioactivity (counts per minute, $\mathrm{CPM}$ ) in a scintillation counter (MicroBeta2 Plate Counter, PerkinElmer).

\section{$\beta$-arrestin 1/2 recruitment}

HEK293T cells $\left(3.5 \times 10^{6}\right.$ cells $\left./ \mathrm{mL}\right)$ were grown for $24 \mathrm{~h}$ before transfection with $4 \mu \mathrm{g}$ plasmid containing a GIPR/SV-Rluc8:Venus- $\beta$-arrestin1/2 at ratio of $1: 9$, or a GIPRRluc8:SV:Venus- $\beta$-arrestin1/2 at a ratio of 1:3:9. Transiently transfected cells were then seeded onto poly-D-lysine coated $96-$ well culture plates $(50,000$ cells/well $)$ in DMEM with 10\% FBS. Cells were grown overnight before incubation in assay buffer (HBSS supplemented with $10 \mathrm{mM}$ HEPES and 0.1\% BSA, pH 7.4) for $30 \mathrm{~min}$ at $37^{\circ} \mathrm{C}$. Coelentrazine-h (Yeasen Biotech) was added to a final concentration of $5 \mu \mathrm{M}$ for $5 \mathrm{~min}$ before bioluminescence resonance energy transfer (BRET) readings were made using 
an EnVision plate reader. BRET baseline measurements were collected for 15 cycles prior to ligand addition. Following peptide addition, BRET was measured for 55 cycles. The BRET signal (ratio of $535 \mathrm{~nm}$ over $470 \mathrm{~nm}$ emission) was corrected to the baseline and then vehicle-treated condition to determine ligand-induced changes in BRET response. Concentration-response values were obtained from the area-under-the-curve (AUC) of the responses elicited by GIP ${ }_{1-42}$.

\section{Immunofluorescence staining}

HEK293T cells were seeded in 6-well plates and transfected with $4 \mu \mathrm{g}$ plasmid containing GIPR-HA or/and SV-FLAG. After $24 \mathrm{~h}$, cells were collected and reseeded in 96-well plates until they reached 50\% 70\% confluence. Cells were washed with PBS before fixation with $4 \%$ paraformaldehyde for $15 \mathrm{~min}$. Then they were washed three more times and blocked with 5\% BSA plus $0.1 \%$ Triton X-100 for $1 \mathrm{~h}$ at RT. Rabbit anti-HA primary antibody (diluted 1:500) or/and mouse anti-FLAG primary antibody (diluted 1:300) were diluted with incubation buffer (PBS supplemented with 5\% BSA) for $1 \mathrm{~h}$ followed by 3-time wash. Cells were reacted with $200 \mu \mathrm{L}$ interaction buffer containing donkey anti-rabbit Alexa 488-conjugated secondary antibody or/and donkey anti-mouse Alexa 647-conjugated secondary antibody (diluted 1:1000) at RT for $1 \mathrm{~h}$ in the dark. After final washing, nuclei were stained with Hoechst 33258 for 5 min. Cells were imaged using a high-resolution microscope DeltaVision ${ }^{\mathrm{TM}}$ Ultra (GE Healthcare, Boston, USA).

\section{G protein NanoBiT assay}

HEK293T cells $\left(3.5 \times 10^{6}\right.$ cells $\left./ \mathrm{mL}\right)$ were grown for $24 \mathrm{~h}$ to reach $70 \%$ to $80 \%$ confluence. Then the cells were transiently transfected with GIPR, G $\alpha_{s}-\mathrm{LgBiT}, \mathrm{G} \beta 1$, and $\mathrm{G} \gamma 2-\mathrm{SmBiT}$ at a 2:1:5:5 mass ratio, or GIPR, SV, Gas-LgBiT, G $\beta 1$, and G $\gamma 2$ SmBiT at a 2:6:1:5:5 mass ratio. Twenty-four hours after transfection, cells were seeded into poly-D-lysine coated 96-well culture plates at a density of 50,000 cells per well in DMEM with 10\% FBS. Cells were grown overnight before incubation in HBSS buffer (pH 7.4) supplemented with $0.1 \%$ BSA and $10 \mathrm{mM}$ HEPES for 30 mins at $37^{\circ} \mathrm{C}$ (no $\left.\mathrm{CO}_{2}\right)$. They were then reacted with coelenterazine $\mathrm{H}(5 \mu \mathrm{M})$ for $2 \mathrm{~h}$ at RT. Luminescence signals were measured using an EnVision plate reader at 15-s intervals 
$\left(25^{\circ} \mathrm{C}\right)$. Briefly, following the baseline reading for $3.5 \mathrm{~min}$, GIP $1-42$ was added, and the reading continued for $13.5 \mathrm{~min}$. Data were corrected to baseline and vehicle-treated samples. The area-under-the-curve (AUC) across the time-course response curve was determined and normalized to the WT GIPR, which was set to $100 \%$.

\section{Molecular dynamics simulation}

Molecular dynamic simulations were performed by Gromacs 2020.1. The homology models of SV1 and SV3 were generated using the cryo-EM structure of the full-length GIPR (PDB code: 7DTY) (Zhao et al., 2021) and the X-ray structure of the GIPR ECD (PDB code: 2QKH) (Parthier et al., 2007) as templates. All peptide-receptor-Gs complexes were built based on the cryo-EM structure of the GIP-GIPR- $\mathrm{G}_{\text {s }}$ complex (PDB code: 7DTY) (Zhao et al., 2021) and prepared by the Protein Preparation Wizard (Schrodinger 2017-4) with the Nb35 nanobody removed. To build the model of peptide-receptor- $\beta$-arrestin 1 complex, the receptor in complex with both peptide and $\mathrm{G}_{\mathrm{s}}$ was aligned to the published $\beta$-arrestin 1-bound $\beta_{1}$ AR structure (PDB code: $6 \mathrm{TKO}$ ) (Lee et al., 2020). The receptor chain termini were capped with acetyl and methylamide. The residues $\mathrm{G} 2$ and $\mathrm{C} 3$ of $\mathrm{G} \alpha$ s were $N$-myristoylated and palmitoylated, respectively (Kato et al., 2019). All missing backbone and side chains were modeled using Prime (Schrodinger 2017-4) and the titratable residues were left in their dominant state at pH 7.0. To build MD simulation systems, the complexes were embedded in a bilayer composed of 254 315 POPC lipids and solvated with $0.15 \mathrm{M} \mathrm{NaCl}$ in explicit TIP3P waters using CHARMM-GUI Membrane Builder v3.6 (Wu et al., 2014). The CHARMM36-CAMP force filed (Guvench et al., 2011) was adopted for protein, peptides, lipids and salt ions. The Particle Mesh Ewald (PME) method was used to treat all electrostatic interactions beyond a cut-off of $12 \AA$ and the bonds involving hydrogen atoms were constrained using LINCS algorithm (Hess, 2008). The complex system was first relaxed using the steepest descent energy minimization, followed by slow heating of the system to $310 \mathrm{~K}$ with restraints. The restraints were reduced gradually over 50 ns. Finally, restrain-free production run was carried out for each simulation, with a time step of $2 \mathrm{fs}$ in the NPT ensemble at $310 \mathrm{~K}$ and 1 bar using the Nose-Hoover thermostat and the semi-isotropic Parrinello-Rahman barostat (Aoki \& Yonezawa, 1992), 
respectively. The buried interface areas were calculated with FreeSASA using the Sharke-Rupley algorithm with a probe radius of $1.2 \AA$ (Mitternacht, 2016).

\section{Statistical analysis}

Statistical analysis was performed using GraphPad Prism 8.4 (GraphPad Software). For signaling assays, data of individual experiments were normalized to the maximum responses in cells expressing only the WT GIPR. Non-linear curve fit was performed using a three-parameter logistic equation (log (agonist vs. response)). All data are presented as means \pm SEM. Significant differences were determined by one-way ANOVA with Dunnett's test. For co-localization analysis, Pearson's correlation coefficients (r) were performed using the co-localization threshold plugin of ImageJ. Five separate Regions of Interest (ROI) were selected and means \pm SEM were determined.

\section{References}

Alexiadou, K., Anyiam, O., \& Tan, T. (2019). Cracking the combination: Gut hormones for the treatment of obesity and diabetes. J Neuroendocrinol, 31(5), e12664. doi:10.1111/jne.12664

Aoki, K. M., \& Yonezawa, F. (1992). Constant-pressure molecular-dynamics simulations of the crystal-smectic transition in systems of soft parallel spherocylinders. Physical Review A, 46(10), 6541-6549. doi:10.1103/physreva.46.6541

Berchiche, Y. A., \& Sakmar, T. P. (2016). CXC Chemokine Receptor 3 Alternative Splice Variants Selectively Activate Different Signaling Pathways. Mol Pharmacol, 90(4), 483-495. doi:10.1124/mol.116.105502

Cai, Z., Schools, G. P., \& Kimelberg, H. K. (2000). Metabotropic glutamate receptors in acutely isolated hippocampal astrocytes: developmental changes of mGluR5 mRNA and functional expression. Glia, 29(1), 70-80. doi:10.1002/(sici)10981136(20000101)29:1<70::aid-glia7>3.0.co;2-v

Campbell, J. E. (2021). Targeting the GIPR for obesity: To agonize or antagonize? Potential mechanisms. Mol Metab, 46, 101139. doi:10.1016/j.molmet.2020.101139

Cho, Y. M., Merchant, C. E., \& Kieffer, T. J. (2012). Targeting the glucagon receptor family for diabetes and obesity therapy. Pharmacol Ther, 135(3), 247-278. doi:10.1016/j.pharmthera.2012.05.009

Cong, Z., Zhou, F., Zhang, C., Zou, X., Zhang, H., Wang, Y., Zhou Q., Cai X., Liu Q., Li J., Shao L., Mao C., Wang X., Wu J., Xia T., Zhao L.-H., Jiang H., Zhang Y., Xu H. E., Cheng X., Yang D., Wang, M.-W. (2021). Constitutive signal bias mediated by the human GHRHR splice variant 1. Proc Natl Acad Sci U S A, 118(40). doi:10.1073/pnas.2106606118 
Coupar, I. M., Desmond, P. V., \& Irving, H. R. (2007). Human 5-HT(4) and 5-HT(7) receptor splice variants: are they important? Curr Neuropharmacol, 5(4), 224231. doi:10.2174/157015907782793621

EMBL-EBI. (2022). Gene: GIPR ENSG00000010310 Structural variants. Ensembl release $105 . \quad$ Retrieved from https://asia.ensembl.org/Homo_sapiens/Gene/StructuralVariation_Gene?db=co re;g=ENSG00000010310;r=19:45668221-45683722

Estall, J. L., \& Drucker, D. J. (2006). Glucagon and glucagon-like peptide receptors as drug targets. Curr Pharm Des, 12(14), 1731-1750. doi:10.2174/138161206776873671

Evans, R. T., \& Seasholtz, A. F. (2009). Soluble corticotropin-releasing hormone receptor 2alpha splice variant is efficiently translated but not trafficked for secretion. Endocrinology, 150(9), 4191-4202. doi:10.1210/en.2009-0285

Furness, S. G., Wootten, D., Christopoulos, A., \& Sexton, P. M. (2012). Consequences of splice variation on Secretin family $\mathrm{G}$ protein-coupled receptor function. $\mathrm{Br} J$ Pharmacol, 166(1), 98-109. doi:10.1111/j.1476-5381.2011.01571.x

Gasbjerg, L. S., Gabe, M. B. N., Hartmann, B., Christensen, M. B., Knop, F. K., Holst, J. J., \& Rosenkilde, M. M. (2018). Glucose-dependent insulinotropic polypeptide (GIP) receptor antagonists as anti-diabetic agents. Peptides, 100, 173-181. doi:10.1016/j.peptides.2017.11.021

GTEx. (2022). Isoform Expression of GIPR: ENSG00000010310.8 gastric inhibitory polypeptide receptor [Source:HGNC Symbol;Acc:HGNC:4271]. (dbGaP Accession phs000424.v8.p2). Retrieved from https:/gtexportal.org/home/gene/GIPR\#gene-transcript-browser-block

Guvench, O., Mallajosyula, S. S., Raman, E. P., Hatcher, E., Vanommeslaeghe, K., Foster, T. J., Jamison F. W. 2nd, Mackerell, A. D., Jr. (2011). CHARMM additive all-atom force field for carbohydrate derivatives and its utility in polysaccharide and carbohydrate-protein modeling. J Chem Theory Comput, 7(10), 3162-3180. doi:10.1021/ct200328p

Hansotia, T., \& Drucker, D. J. (2005). GIP and GLP-1 as incretin hormones: lessons from single and double incretin receptor knockout mice. Regul Pept, 128(2), 125-134. doi:10.1016/j.regpep.2004.07.019

Harada, N., Yamada, Y., Tsukiyama, K., Yamada, C., Nakamura, Y., Mukai, E., Hamasaki A., Liu X., Toyoda K., Seino Y., Inagaki, N. (2008). A novel GIP receptor splice variant influences GIP sensitivity of pancreatic beta-cells in obese mice. Am J Physiol Endocrinol Metab, 294(1), E61-68. doi:10.1152/ajpendo.00358.2007

Harris, M., Mackie, D. I., Pawlak, J. B., Carvalho, S., \& Ladds, G. (2021). RAMPs regulate signalling bias and internalisation of the GIPR.

Hess, B. (2008). P-LINCS: A Parallel Linear Constraint Solver for Molecular Simulation. J Chem Theory Comput, 4(1), 116-122. doi:10.1021/ct700200b

Joun, H., Lanske, B., Karperien, M., Qian, F., Defize, L., \& Abou-Samra, A. (1997). Tissue-specific transcription start sites and alternative splicing of the parathyroid hormone (PTH)/PTH-related peptide (PTHrP) receptor gene: a new 
PTH/PTHrP receptor splice variant that lacks the signal peptide. Endocrinology, 138(4), 1742-1749. doi:10.1210/endo.138.4.5085

Karpa, K. D., Lin, R., Kabbani, N., \& Levenson, R. (2000). The dopamine D3 receptor interacts with itself and the truncated D3 splice variant d3nf: D3-D3nf interaction causes mislocalization of D3 receptors. Mol Pharmacol, 58(4), 677683. doi:10.1124/mol.58.4.677

Kato, H. E., Zhang, Y., Hu, H., Suomivuori, C. M., Kadji, F. M. N., Aoki, J., Krishna Kumar K., Fonseca R., Hilger D., Huang W., Latorraca N. R., Inoue A., Dror R. O., Kobilka B. K., Skiniotis, G. (2019). Conformational transitions of a neurotensin receptor 1-Gil complex. Nature, 572(7767), 80-85. doi:10.1038/s41586-019-1337-6

Killion, E. A., Wang, J., Yie, J., Shi, S. D., Bates, D., Min, X., Komorowski R., Hager T., Deng L., Atangan L., Lu S.-C, Kurzeja R. J. M, Sivits G., Lin J., Chen Q., Wang Z., Thibault S. A., Abbott C. M., Meng T., Clavette B., Murawsky C. M., Foltz I. N., Rottman J. B., Hale C., Véniant M. M., Lloyd, D. J. (2018). Antiobesity effects of GIPR antagonists alone and in combination with GLP-1R agonists in preclinical models. Sci Transl Med, 10(472). doi:10.1126/scitranslmed.aat3392

Kochman, K. (2014). Superfamily of G-protein coupled receptors (GPCRs)-extraordinary and outstanding success of evolution. Postepy Hig Med Dosw (Online), 68, 1225-1237. doi:10.5604/17322693.1127326

Lee, Y., Warne, T., Nehme, R., Pandey, S., Dwivedi-Agnihotri, H., Chaturvedi, M., Edwards P. C., García-Nafría J., Leslie A. G. W., Shukla A. K., Tate, C. G. (2020). Molecular basis of beta-arrestin coupling to formoterol-bound beta1adrenoceptor. Nature, 583(7818), 862-866. doi:10.1038/s41586-020-2419-1

Lu, Z., Xu, J., Rossi, G. C., Majumdar, S., Pasternak, G. W., \& Pan, Y. X. (2015). Mediation of opioid analgesia by a truncated 6-transmembrane GPCR. J Clin Invest, 125(7), 2626-2630. doi:10.1172/JCI81070

Maggio, R., Fasciani, I., Rossi, M., Di Gregorio, J., Pietrantoni, I., Puca, V., Flati V., Scarselli, M. (2016). Variants of G protein-coupled receptors: a reappraisal of their role in receptor regulation. Biochem Soc Trans, 44(2), 589-594. doi:10.1042/BST20150239

Markovic, D., \& Challiss, R. A. (2009). Alternative splicing of G protein-coupled receptors: physiology and pathophysiology. Cell Mol Life Sci, 66(20), 33373352. doi:10.1007/s00018-009-0093-4

Marti-Solano, M., Crilly, S. E., Malinverni, D., Munk, C., Harris, M., Pearce, A., Quon T., Mackenzie A. E., Wang X., Peng J., Tobin A. B/, Ladds G., Milligan G., Gloriam D. E., Puthenveedu M. A., Babu, M. M. (2020). Combinatorial expression of GPCR isoforms affects signalling and drug responses. Nature, 587(7835), 650-656. doi:10.1038/s41586-020-2888-2

McCulloch, D. A., Lutz, E. M., Johnson, M. S., Robertson, D. N., MacKenzie, C. J., Holland, P. J., \& Mitchell, R. (2001). ADP-ribosylation factor-dependent phospholipase D activation by VPAC receptors and a PAC(1) receptor splice variant. Mol Pharmacol, 59(6), 1523-1532. doi:10.1124/mol.59.6.1523 
422

423

424

425

426

427

428

429

430

431

432

433

434

435

436

437

438

439

440

441

442

443

444

445

446

447

448

449

450

451

452

453

454

455

456

457

458

459

460

461

462

463

464

465

Mitternacht, S. (2016). FreeSASA: An open source C library for solvent accessible $\begin{array}{lllll}\text { surface area calculations. F1000Res, } & \text { 5, }\end{array}$ doi:10.12688/f1000research.7931.1

Nag, K., Sultana, N., Kato, A., \& Hirose, S. (2007). Headless splice variant acting as dominant negative calcitonin receptor. Biochem Biophys Res Commun, 362(4), 1037-1043. doi:10.1016/j.bbrc.2007.08.107

NCBI. (2022a). Gastric inhibitory polypeptide receptor isoform X6 [Homo sapiens]. v109.20211119. Retrieved from https://www.ncbi.nlm.nih.gov/protein/XP_016882074.1

NCBI. (2022b). Gastric inhibitory polypeptide receptor isoform X9 [Homo sapiens]. v109.20211119. Retrieved from https://www.ncbi.nlm.nih.gov/protein/XP_011525018.1

Parthier, C., Kleinschmidt, M., Neumann, P., Rudolph, R., Manhart, S., Schlenzig, D., Fanghänel J., Rahfeld J.-U., Demuth H.-U., Stubbs, M. T. (2007). Crystal structure of the incretin-bound extracellular domain of a $\mathrm{G}$ protein-coupled receptor. Proc Natl Acad Sci $U$ S A, 104(35), 13942-13947. doi:10.1073/pnas.0706404104

Pavlos, N. J., \& Friedman, P. A. (2017). GPCR Signaling and Trafficking: The Long and Short of It. Trends Endocrinol Metab, 28(3), 213-226. doi:10.1016/j.tem.2016.10.007

Richtand, N. M. (2006). Behavioral sensitization, alternative splicing, and d3 dopamine receptor-mediated inhibitory function. Neuropsychopharmacology, 31(11), 2368-2375. doi:10.1038/sj.npp.1301163

Seino, Y., Fukushima, M., \& Yabe, D. (2010). GIP and GLP-1, the two incretin hormones: Similarities and differences. J Diabetes Investig, 1(1-2), 8-23. doi:10.1111/j.2040-1124.2010.00022.x

Sekar, R., Singh, K., Arokiaraj, A. W., \& Chow, B. K. (2016). Pharmacological Actions of Glucagon-Like Peptide-1, Gastric Inhibitory Polypeptide, and Glucagon. Int Rev Cell Mol Biol, 326, 279-341. doi:10.1016/bs.ircmb.2016.05.002

Shao, L., Chen, Y., Zhang, S., Zhang, Z., Cao, Y., Yang, D., \& Wang, M.-W. (2021). Modulating effects of RAMPs on signaling profiles of the glucagon receptor family. Acta Pharm Sin B. doi:10.1016/j.apsb.2021.07.028

Skow, M. A., Bergmann, N. C., \& Knop, F. K. (2016). Diabetes and obesity treatment based on dual incretin receptor activation: 'twincretins'. Diabetes Obes Metab, 18(9), 847-854. doi:10.1111/dom.12685

Strange, P. G. (2008). Signaling mechanisms of GPCR ligands. Curr Opin Drug Discov Devel, 11(2), 196-202.

Wu, E. L., Cheng, X., Jo, S., Rui, H., Song, K. C., Davila-Contreras, E. M., Qi Y., Lee J., Monje-Galvan V., Venable R. M., Klauda J. B., Im, W. (2014). CHARMMGUI Membrane Builder toward realistic biological membrane simulations. $J$ Comput Chem, 35(27), 1997-2004. doi:10.1002/jcc.23702

Yabe, D., \& Seino, Y. (2011). Two incretin hormones GLP-1 and GIP: comparison of their actions in insulin secretion and beta cell preservation. Prog Biophys Mol Biol, 107(2), 248-256. doi:10.1016/j.pbiomolbio.2011.07.010 
466

467

468

469

470

471

472

473

474

475

476

477

478

479

480

481

482

483

484

485

486

487

488

489

Yue, J. T. Y., \& Lam, T. K. T. (2019). Antiobesogenic effects of central GIPR antagonism. J Clin Invest, 129(9), 3532-3535. doi:10.1172/JCI130755

Zhao, F., Zhang, C., Zhou, Q., Hang, K., Zou, X., Chen, Y., Wu F., Rao Q., Dai A., Yin W., Shen D.-D., Zhang Y., Xia T., Stevens R. C., Xu H. E., Yang D., Zhao L., Wang, M.-W. (2021). Structural insights into hormone recognition by the human glucose-dependent insulinotropic polypeptide receptor. Elife, 10, e68719. doi:10.7554/eLife.68719

\section{Acknowledgments}

We are grateful to Dr. Zhaotong Cong, Ms. Yan Chen and Mr. Chao Zhang for technical assistance. This work was partially supported by National Natural Science Foundation of China 81872915 (M.-W.W.), 82073904 (M.-W.W.), 82121005 (D.Y.), 81973373 (D.Y.) and 21704064 (Q.Z.); National Science \& Technology Major Project of ChinaKey New Drug Creation and Manufacturing Program 2018ZX09735-001 (M.-W.W.) and 2018ZX09711002-002-005 (D.Y.); National Science \& Technology Major Project of China - Innovation 2030 for Brain Science and Brain-Inspired Technology $2021 Z$ D0203400 (Q.Z.); the National Key Basic Research Program of China 2018YFA0507000 (M.-W.W.); Novo Nordisk-CAS Research Fund grant NNCAS2017-1-CC (D.Y.) and SA-SIBS Scholarship Program (D.Y.).

Author contributions: D.Y. and M.-W.W. designed research; K.H., L.S., F.Z., A.D., and X.C. performed research; K.H., L.S., Q.Z., R.C.S. and D.Y. analyzed data; and K.H., L.S., and M.-W.W. wrote the paper.

Competing interests: Authors declare that they have no competing interests.

Data availability: All data generated or analyzed during this study are included in the manuscript. Source data files have been provided for Figures 2-6. 
A

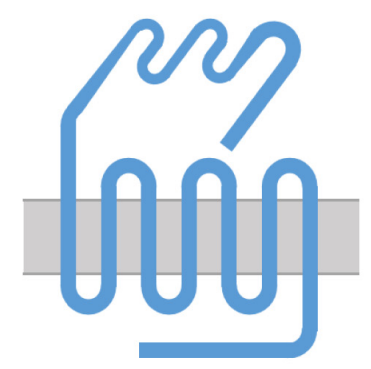

C

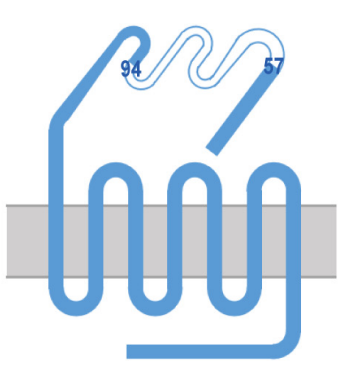

$\mathbf{F}$

GIPR
SV1
SV2
SV3
SV4
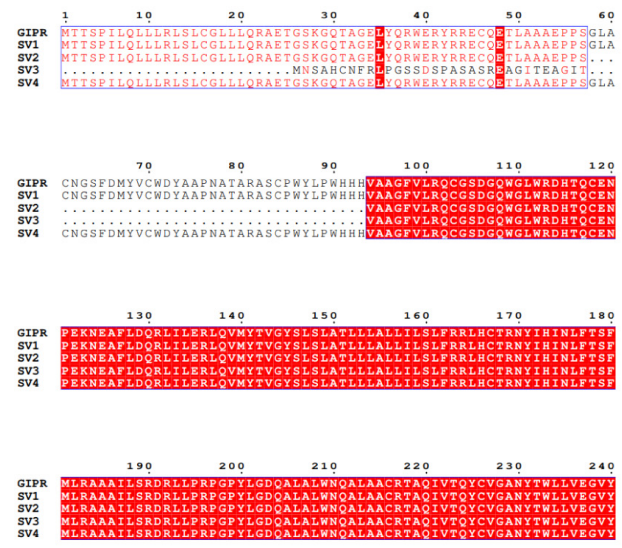

B

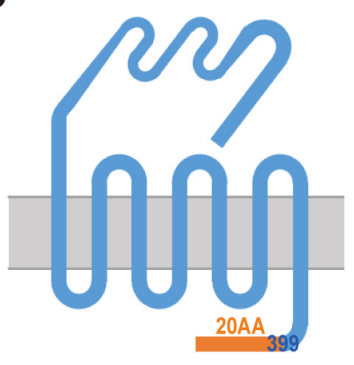

D

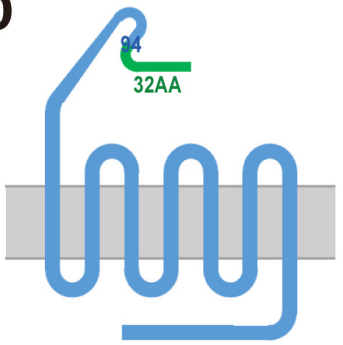

E

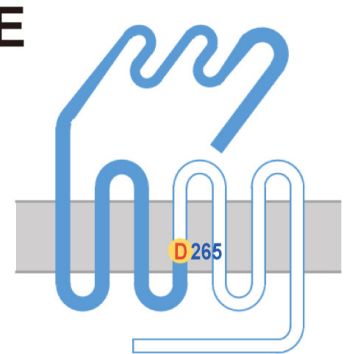

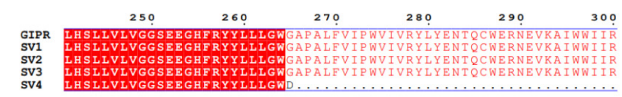
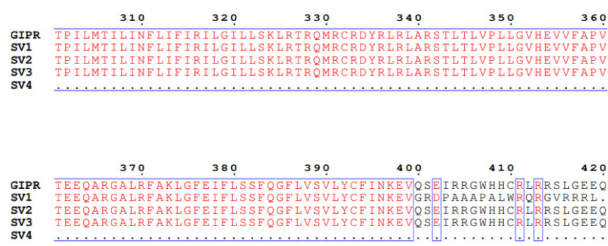

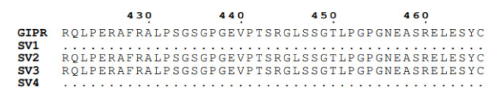

Figure 1. Schematic diagram of GIPR and its splice variant (SV) constructs. A, Construct of the wild-type (WT) GIPR. B, Construct of SV1. Residues 400-466 are replaced by a 20-amino acid sequence (GRDPAAAPALWRQRGVRRRL). C, Construct of SV2. Residues 58-93 are missing compared to that of WT. D, Construct of SV3. Residues 1-93 are replaced by a 32-amino acid sequence (MNSAHCNFRLPGSSDSPASASREAGITEAGIT). E, Construct of SV4. Residues 266-466 are missing and G265 is replaced by aspartic acid (D). F, Sequence alignment of GIPR and the four SVs. 
A

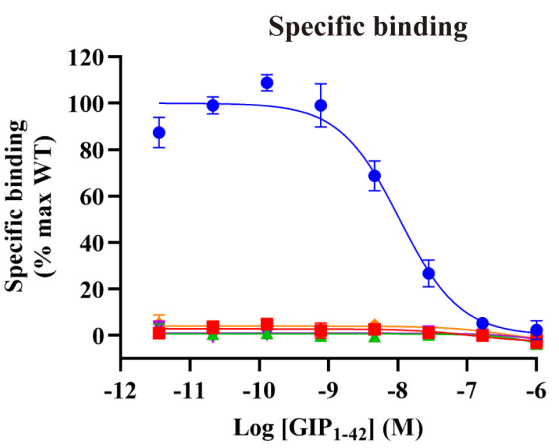

C

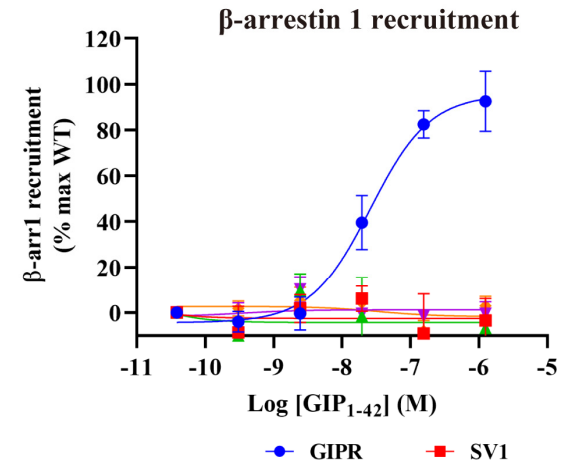

B

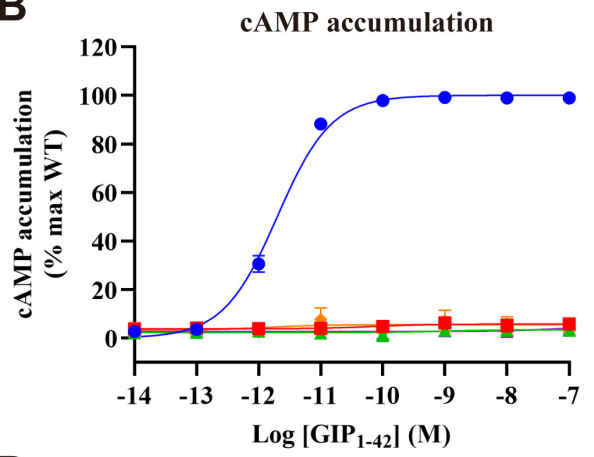

D

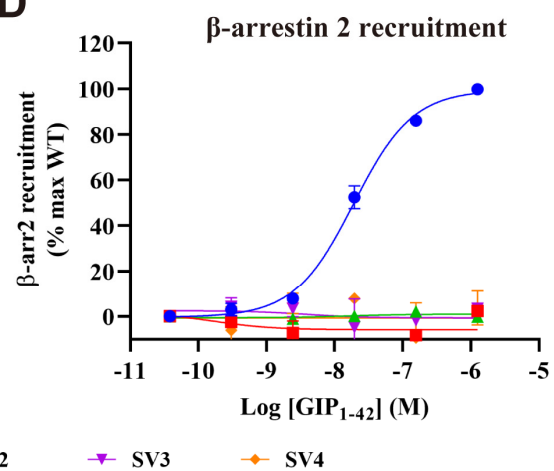

Figure 2. Ligand-binding and signaling profiles of GIPR and its splice variants (SVs). A, Competitive inhibition of ${ }^{125}$ I-GIP1-42 $_{1}$ binding to GIPR and SVs by unlabeled GIP142. Binding affinity is quantified by reduction of radioactivity (counts per minute, CPM). B, Concentration-response curves of cAMP accumulation elicited by GIP1-42 at GIPR and SVs. C and D, $\beta$-arrestins 1 ( $\beta$-arr1) and 2 ( $\beta$-arr2) recruitment by GIPR and SVs. Concentration-response characteristics are shown as the area-under-the-curve (AUC) across the time-course response curve (0 to $10 \mathrm{~min})$ for each concentration. Data shown are means \pm SEM of at least three independent experiments $(n=3-5)$ performed in quadruplicate (cAMP accumulation) or duplicate (specific binding and $\beta$-arrestin recruitment). Signals were normalized to the maximum (max) response of the wild-type (WT) GIPR and concentration-response curves were analyzed using a three-parameter logistic equation.

The following figure supplements are available for figure 2:

Source data 1. Ligand-binding and signaling profiles of GIPR and its splice variants (SVs). 
A

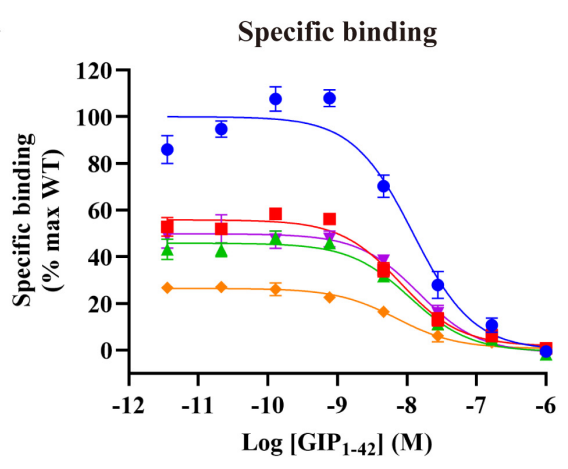

C

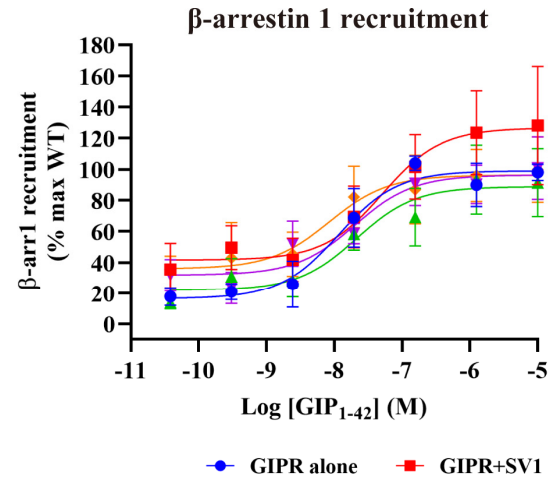

B

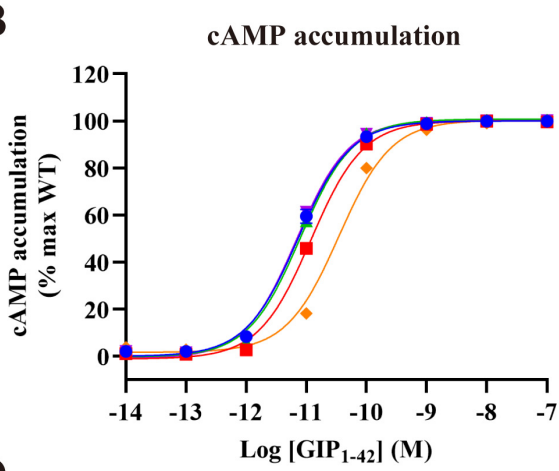

$\mathbf{D}$

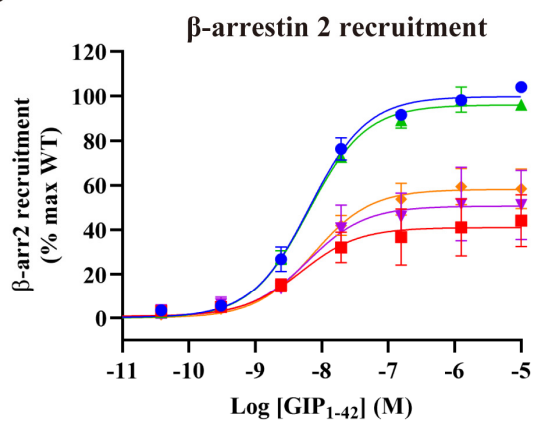

518 Figure 3. Effects of GIPR splice variants (SVs) on ligand binding and the wild-type (WT) GIPR mediated signal transduction in HEK293T cells co-expressing GIPR and individual SVs. A, Effects of SVs on competitive binding of ${ }^{125} \mathrm{I}_{-} \mathrm{GIP}_{1-42}$ to GIPR. B, Effects of SVs on GIP1-42 induced cAMP accumulation at GIPR. C and D, Effects of SVs and GIPR on $\beta$-arrestins 1 ( $\beta$-arr1) and $2(\beta$-arr2) recruitment by GIPR. Cells were co-transfected with GIPR and each SV at a 1:3 ratio. Data shown are means \pm SEM of at least three independent experiments $(n=3-5)$ performed in quadruplicate (cAMP accumulation) or duplicate (specific binding and $\beta$-arrestin recruitment). Signals were normalized to the maximum $(\max )$ response of GIPR and concentration-response curves were analyzed using a three-parameter logistic equation. The following figure supplements are available for figure 3: type (WT) GIPR mediated signal transduction in HEK293T cells co-expressing GIPR and individual SVs. 
A

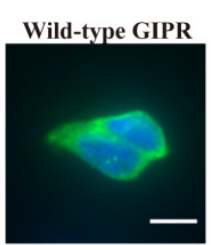

B

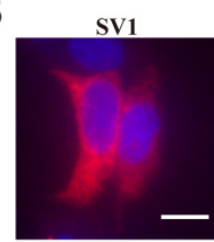

SV3

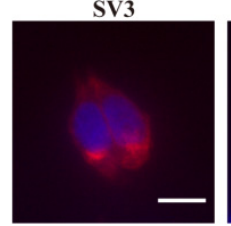

SV2

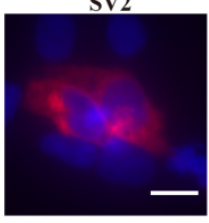

SV4

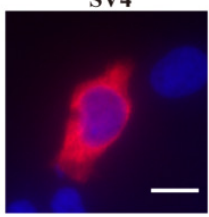

C
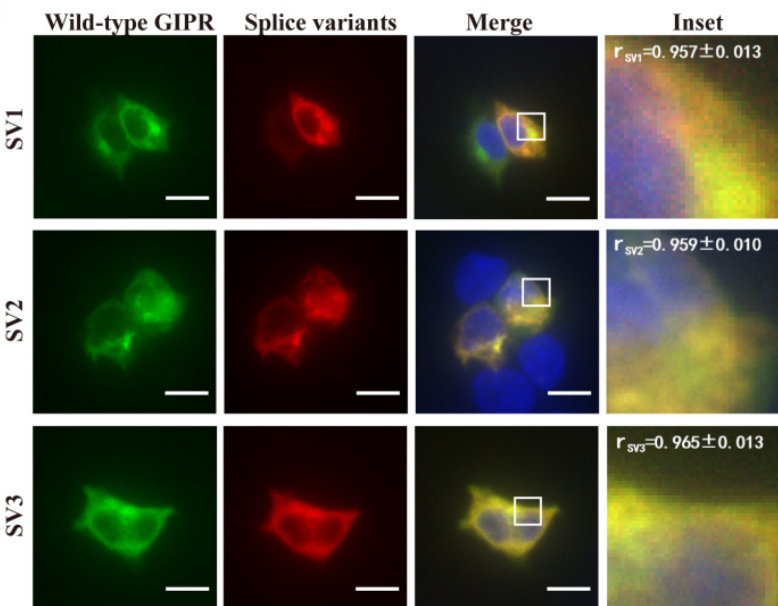

$r_{s / 2}=0.959 \pm 0.010$
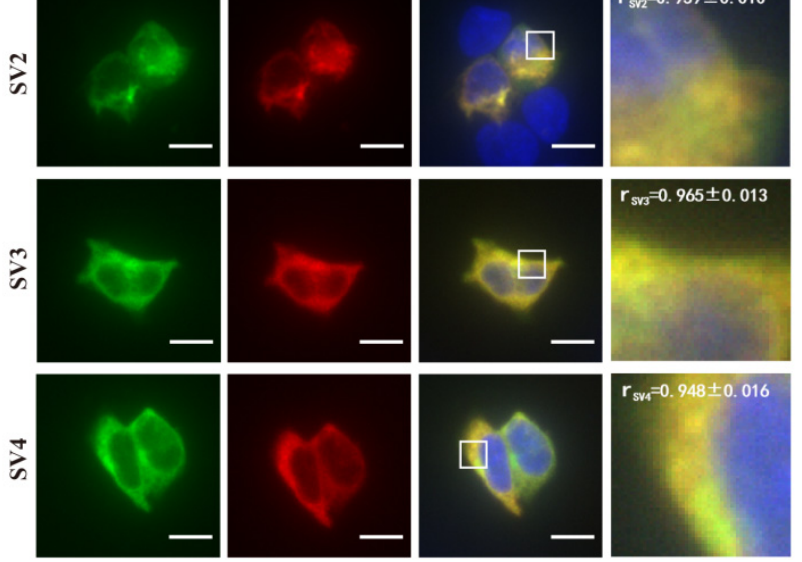

534 Figure 4. Co-localization of GIPR and its splice variants (SVs). Immunofluorescence 535 staining of HEK293T cells transfected with GIPR-HA (A) or each SV-FLAG (B) alone.

536 To estimate their co-localization, co-transfection of GIPR and individual SVs (C) was

537 performed at a ratio of 1:3 (green, GIPR-HA; red, SV-FLAG; yellow, merge). Data show representative results from three independent experiments. Inset demonstrates the overlapping positions of GIPR and SVs in the cell surface (SV1, SV3 and SV4) or

540 cytoplasm (SV2). Cells were observed by DeltaVision ${ }^{\text {TM }}$ Ultra. Scale bar $=10 \mu \mathrm{m}$.

541 The following figure supplements are available for figure 4:

542 Source data 1. Co-localization of GIPR and its splice variants (SVs). 
A

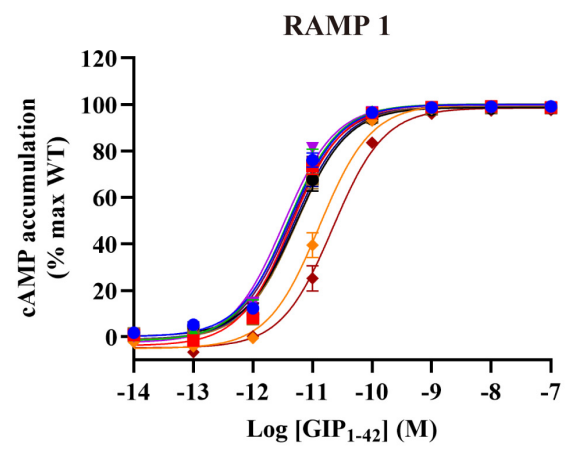

C

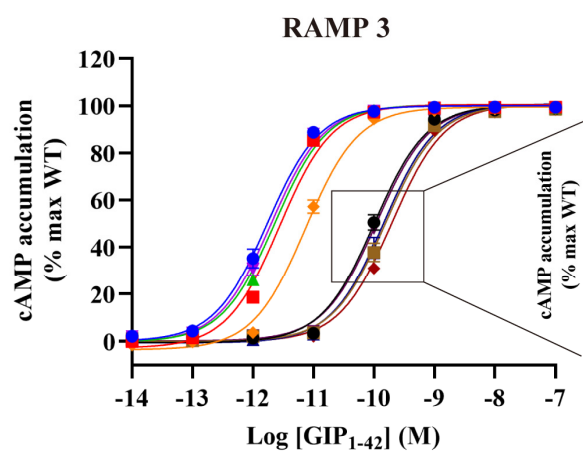

B

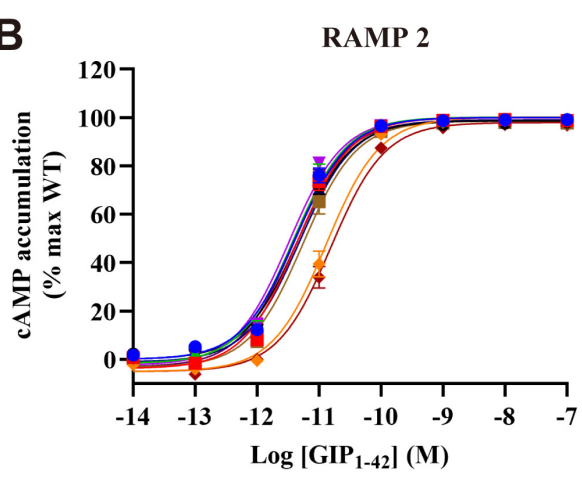

- GIPR alone

- GIPR+SV1+vector

- GIPR+SV2+vector

$\rightarrow$ GIPR+SV3+vector

- GIPR+SV4+vector

- GIPR+vector+RAMP

- GIPR+SV1+RAMP

^ GIPR+SV2+RAMP

$\rightarrow$ GIPR+SV3+RAMP

$\rightarrow$ GIPR+SV4+RAMP

545 Figure 5. Synergistic effects of splice variants (SVs) and receptor activity-modifying

546 proteins (RAMPs) on GIPR-mediated cAMP signaling in HEK293T cells coexpressing GIPR, each SV and RAMP1 (A), RAMP2 (B) or RAMP3 (C). Signals were normalized to the maximum ( $\max$ ) response of the wild-type (WT) GIPR and data were fitted with a non-linear regression of three-parameter logistic curve. Data shown are means \pm SEM of three independent experiments performed in quadruplicate. The following figure supplements are available for figure 5: Source data 1. Effects of splice variants (SVs) and receptor activity-modifying proteins (RAMPs) on GIPR-mediated cAMP signaling in HEK293T cells co-expressing GIPR, each SV and RAMP1. 


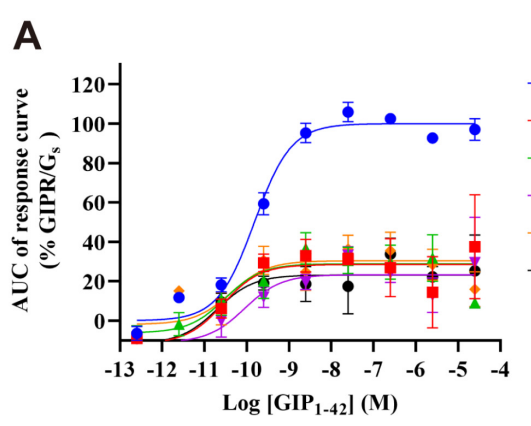

C

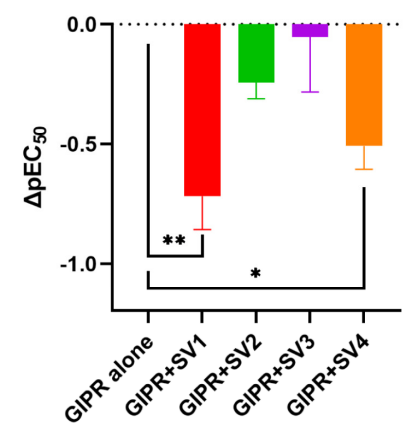

B

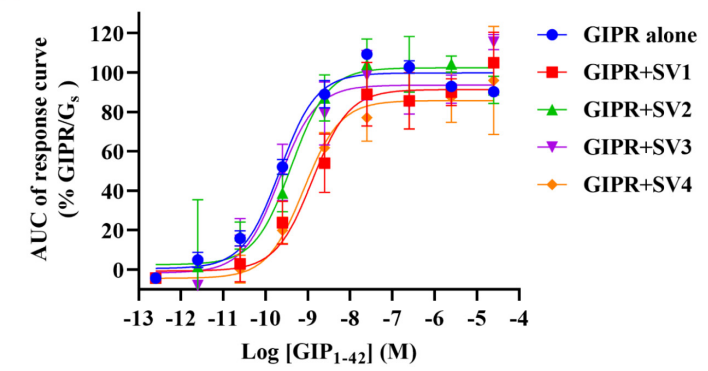

D

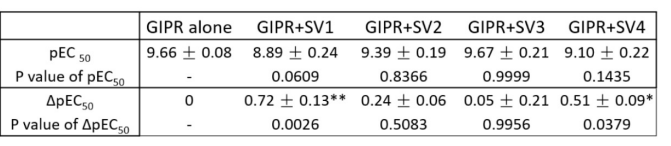

556

557

558

559

560

561

562

563

564

565

566

567

568

569

570

571

572

573

Figure 6. Effects of GIPR splice variants (SVs) on the wild-type (WT) GIPR mediated Gs protein coupling in HEK293T cells co-expressing GIPR and individual SVs. A, GIP1-42-induced $\mathrm{G}_{\mathrm{s}}$ coupling of individually expressed SVs and GIPR. Concentrationresponse curves are expressed as area-under-the-curse (AUC) across the time-course response curve (0 to $13.5 \mathrm{~min}$ ) for each concentration and normalized to WT GIPR. B, Effects of SVs on GIP $1-42$ induced $\mathrm{G}_{\mathrm{s}}$ protein coupling at GIPR. C, EC50 differences of GIPR mediated Gs protein coupling under the influence of SVs. D, Gs protein coupling profiles of GIPR affected by SVs. Cells were co-transfected with GIPR and each SV at a 1:3 ratio. Data shown are means \pm SEM of six independent experiments performed in duplicate. Signals were normalized to the maximum (max) response of GIPR and concentration-response curves were analyzed using a three-parameter logistic equation. $* \mathrm{P}<0.05 ; * * \mathrm{P}<0.01$.

The following figure supplements are available for figure 6 :

Source data 6. Effects of GIPR splice variants (SVs) on the wild-type (WT) GIPR mediated $\mathrm{G}_{\mathrm{s}}$ protein coupling in HEK293T cells co-expressing GIPR and individual SVs. 

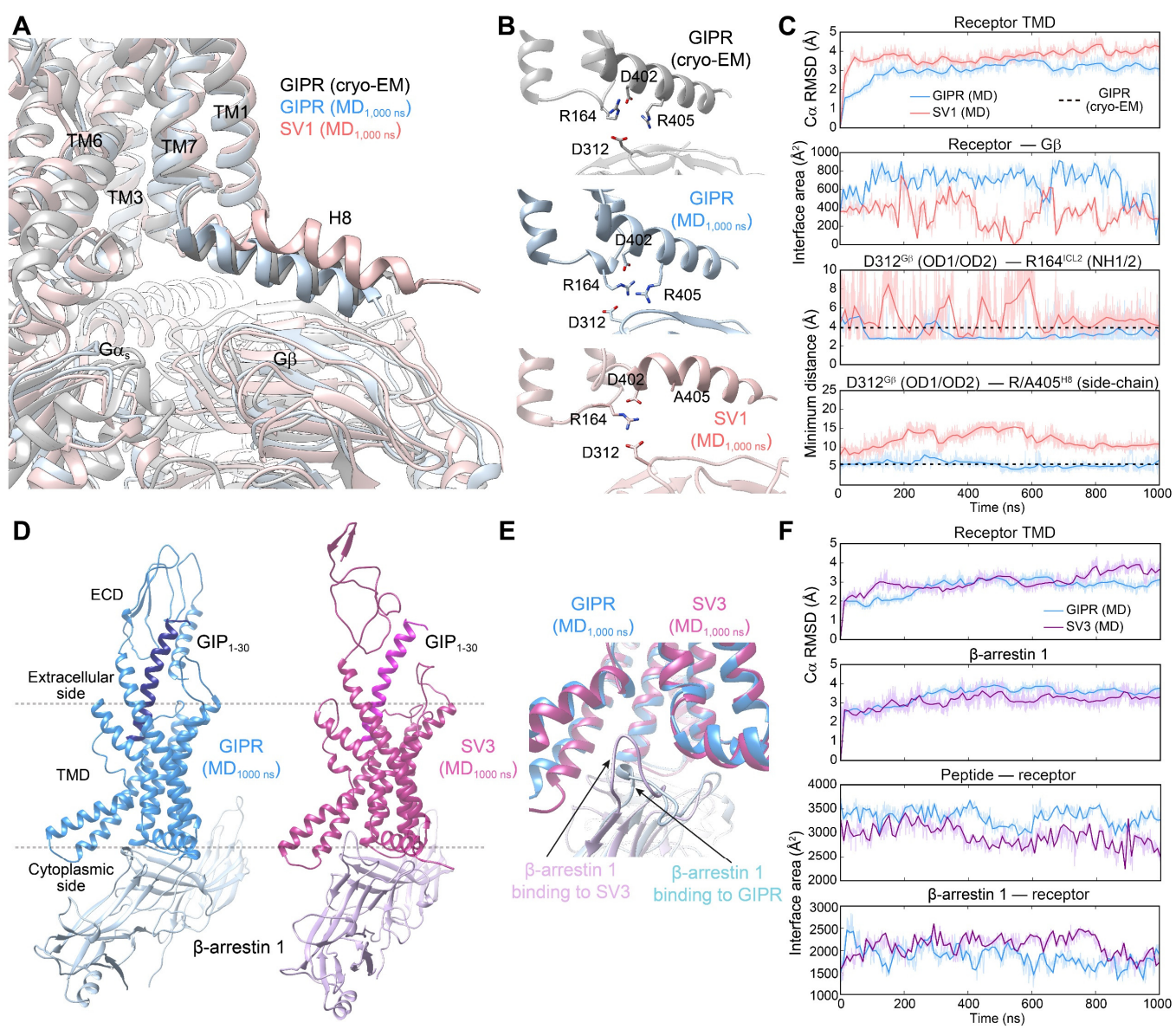

Figure 7. Molecular dynamics (MD) simulations of SV1 and SV3. A, Comparison of receptor- $\mathrm{G}_{\mathrm{s}}$ conformation between the cryo-EM structure and final simulation snapshots of SV 1 and GIPR. B, Comparison of the H8-G $\beta$ interface between GIPR and SV1. C, Analysis of the MD simulation trajectories in (A): top, root mean square deviation (RMSD) of $\mathrm{C} \alpha$ positions of the receptor TMD, where all snapshots were superimposed on the cryo-EM structure of both GIP- and Gs-bound GIPR TMD (PDB code: 7DTY) using the $\mathrm{C} \alpha$ atom; upper middle, the buried surface area between receptor and $\mathrm{G} \beta$, interface areas were calculated using freeSASA; lower middle, minimum distances between the charged atoms of $\mathrm{D} 312^{\mathrm{G} \beta}$ and $\mathrm{R} 164^{\mathrm{ICL} 2}$ during MD simulations; bottom, minimum distances between the charged atoms of $\mathrm{D} 312^{\mathrm{G} \beta}$ and the side-chain atoms of $\mathrm{R} 405^{\mathrm{H} 8}$ (GIPR) or $\mathrm{A} 405^{\mathrm{H} 8}$ (SV1) during MD simulations. D, Comparison of the final MD snapshots between GIPR- $\beta$-arrestin 1 and SV3- $\beta$-arrestin 1 . E, Different $\beta$-arrestin 1 modes between GIPR and SV3 according to MD simulations. F, Analysis of the MD simulation trajectories in (D): top, C $\alpha$ RMSD of the receptor TMD, where all snapshots were superimposed on the cryo-EM structure of both GIP- and Gs-bound GIPR TMD (PDB code: 7DTY); upper middle, C $\alpha$ RMSD calculation for $\beta$-arrestin 1 , where all snapshots were superimposed on the cryo-EM structure of $\beta_{1}$ AR-bound $\beta$ arrestin 1 (PDB code: 6TKO) using the $\mathrm{C} \alpha$ atom; lower middle, the buried surface area between receptor and peptide during MD simulations; bottom, the buried surface area between receptor and $\beta$-arrestin 1 during MD simulations. 
A

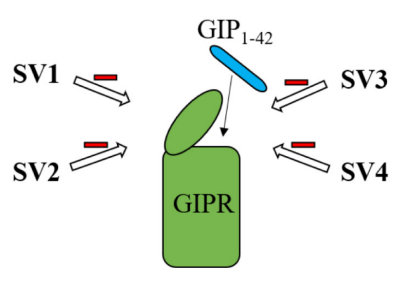

D

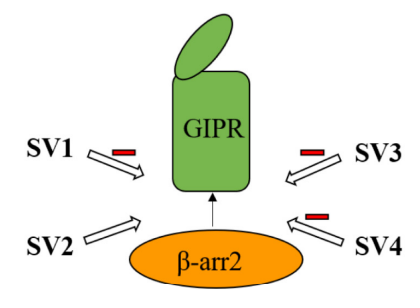

B

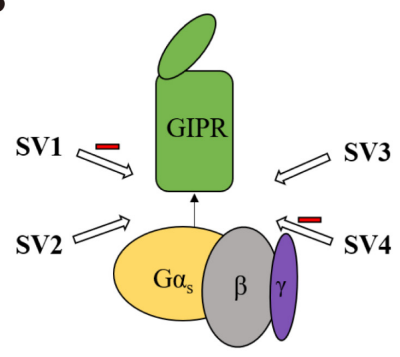

C

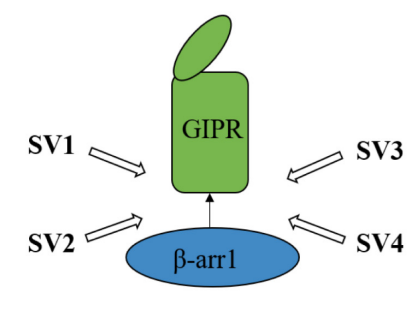

E

\begin{tabular}{ccccc}
\hline & SV1 & SV2 & SV3 & SV4 \\
\hline $\begin{array}{c}\text { Binding } \\
(\text { Span) }\end{array}$ & $0.56^{* * *}$ & $0.46^{* * *}$ & $0.50^{* * *}$ & $0.26^{* * *}$ \\
\hline $\begin{array}{c}\text { cAMP } \\
\left(\mathbf{E C}_{50}\right)\end{array}$ & $1.64^{* * *}$ & 1.09 & 0.95 & $4.79^{* * *}$ \\
\hline $\begin{array}{c}\mathbf{G}_{5} \\
\left(\Delta E C_{50}\right)\end{array}$ & $5.89^{* *}$ & 1.88 & 0.98 & $3.68^{*}$ \\
\hline $\begin{array}{c}\beta-a r r 1 \\
\left(\mathbf{E}_{\max }\right)\end{array}$ & 1.28 & 0.90 & 0.97 & 0.97 \\
\hline $\begin{array}{c}\text { B-arr2 } \\
\left(\mathbf{E}_{\max }\right)\end{array}$ & $0.41^{* * *}$ & 0.96 & $0.51^{* * *}$ & $0.58^{* * *}$ \\
\hline
\end{tabular}

- Negative modulation

596 Figure 8. Characterization of the effects of SVs on ligand binding and signaling profiles 597 in HEK293T cells co-expressing GIPR and individual SVs. A-D, Schematic diagram 598 representing the effects of SVs on ligand binding (A), cAMP signaling and $\mathrm{G}_{\mathrm{s}}$ activation 599 (B), $\beta$-arrestins 1 ( $\beta$-arr1) (C) and 2 ( $\beta$-arr2) recruitment (D). E, Ratio of parameters of 600 ligand binding and signaling to GIPR alone. One-way ANOVA were used to determine 601 statistical difference $(* \mathrm{P}<0.05, * * \mathrm{P}<0.01, * * * \mathrm{P}<0.0001)$. 
603 Table 1. Effects of splice variants (SVs) on ligand binding and GIPR-mediated signal transduction in HEK293T cells co-expressing GIPR and

\begin{tabular}{|c|c|c|c|c|c|c|c|c|c|c|}
\hline & \multicolumn{2}{|c|}{ Ligand binding } & \multicolumn{2}{|c|}{ cAMP accumulation } & \multicolumn{2}{|c|}{ Gs coupling } & \multicolumn{2}{|c|}{$\beta$-arr1 recruitment } & \multicolumn{2}{|c|}{$\beta$-arr2 recruitment } \\
\hline & $\mathrm{pIC}_{50} \pm \mathrm{SEM}$ & Span $(\%) \pm$ SEM & $\mathrm{pEC}_{50} \pm \mathrm{SEM}$ & $\mathrm{E}_{\max }(\%) \pm \mathrm{SEM}$ & $\mathrm{pEC}_{50} \pm \mathrm{SEM}$ & $\mathrm{E}_{\max }(\%) \pm \mathrm{SEM}$ & $\mathrm{pEC}_{50} \pm \mathrm{SEM}$ & $\mathrm{E}_{\max }(\%) \pm \mathrm{SEM}$ & $\mathrm{pEC}_{50} \pm \mathrm{SEM}$ & $\mathrm{E}_{\max }(\%) \pm \mathrm{SEM}$ \\
\hline WT GIPR & $7.91 \pm 0.10$ & $100.00 \pm 4.87$ & $11.14 \pm 0.02$ & $100.00 \pm 0.63$ & $9.66 \pm 0.08$ & $99.79 \pm 2.20$ & $7.94 \pm 0.26$ & $99.03 \pm 6.83$ & $8.19 \pm 0.06$ & $99.78 \pm 1.81$ \\
\hline GIPR+SV1 & $8.09 \pm 0.09$ & $54.21 \pm 2.27^{*}$ & $10.92 \pm 0.02 *$ & $100.08 \pm 0.50$ & $8.89 \pm 0.24$ & $91.36 \pm 6.42$ & $7.29 \pm 0.52$ & $126.65 \pm 16.04$ & $8.32 \pm 0.35^{*}$ & $40.99 \pm 4.17$ \\
\hline GIPR+SV2 & $7.96 \pm 0.11$ & $46.52 \pm 2.30^{*}$ & $11.10 \pm 0.02$ & $100.79 \pm 0.52$ & $9.39 \pm 0.19$ & $102.39 \pm 5.10$ & $7.67 \pm 0.44$ & $88.87 \pm 9.90$ & $8.21 \pm 0.06$ & $96.02 \pm 1.69$ \\
\hline GIPR+SV3 & $7.82 \pm 0.13$ & $51.01 \pm 3.26^{*}$ & $11.16 \pm 0.02$ & $100.38 \pm 0.43$ & $9.67 \pm 0.21$ & $93.61 \pm 5.31$ & $7.70 \pm 0.39$ & $96.31 \pm 8.45$ & $8.22 \pm 0.34^{*}$ & $50.62 \pm 5.12$ \\
\hline GIPR+SV4 & $8.15 \pm 0.13$ & $25.77 \pm 1.59^{*}$ & $10.46 \pm 0.02 *$ & $100.38 \pm 0.68$ & $9.10 \pm 0.22$ & $85.77 \pm 5.40$ & $8.08 \pm 0.60$ & $96.27 \pm 10.78$ & $8.13 \pm 0.16^{*}$ & $58.17 \pm 2.88$ \\
\hline
\end{tabular}

cAMP accumulation, Gs activation and $\beta$-arrestin 1/2 recruitment assays were performed in HEK293T cells. Whole cell binding assay was

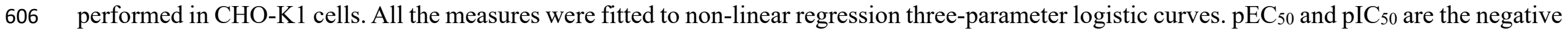

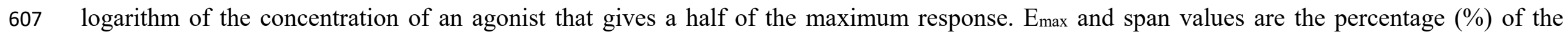

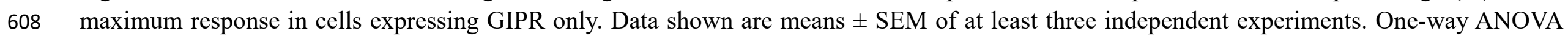


611 Table 2. Synergistic effects of splice variants (SVs) and receptor activity-modifying

612 proteins (RAMPs) on GIPR-mediated cAMP signaling in HEK293T cells co613 expressing GIPR.

\begin{tabular}{ccccccc}
\hline & \multicolumn{5}{c}{ AAMP accumulation } \\
\cline { 2 - 7 } & \multicolumn{2}{c}{ RAMP1 } & \multicolumn{2}{c}{ RAMP2 } & \multicolumn{2}{c}{ RAMP3 } \\
& $\mathrm{pEC}_{50} \pm \mathrm{SEM}$ & $\mathrm{E}_{\max }(\%) \pm \mathrm{SEM}$ & $\mathrm{pEC}_{50} \pm \mathrm{SEM}$ & $\mathrm{E}_{\max }(\%) \pm \mathrm{SEM}$ & $\mathrm{pEC}_{50} \pm \mathrm{SEM}$ & $\mathrm{E}_{\max }(\%) \pm \mathrm{SEM}$ \\
\hline GIPR & $11.39 \pm 0.03$ & $100.00 \pm 0.88$ & $11.39 \pm 0.03$ & $100.00 \pm 0.88$ & $11.76 \pm 0.03$ & $100.00 \pm 0.78$ \\
SV1 & $11.36 \pm 0.04$ & $100.00 \pm 0.96$ & $11.36 \pm 0.04$ & $100.00 \pm 0.96$ & $11.56 \pm 0.03^{\mathrm{b}}$ & $100.47 \pm 0.67$ \\
SV2 & $11.42 \pm 0.04$ & $100.17 \pm 1.11$ & $11.42 \pm 0.04$ & $100.17 \pm 1.11$ & $11.64 \pm 0.03^{\mathrm{a}}$ & $100.40 \pm 0.73$ \\
SV3 & $11.48 \pm 0.04$ & $99.89 \pm 0.89$ & $11.48 \pm 0.04$ & $99.89 \pm 0.89$ & $11.70 \pm 0.03$ & $100.08 \pm 0.62$ \\
SV4 & $10.89 \pm 0.04^{\mathrm{b}}$ & $100.15 \pm 1.18$ & $10.89 \pm 0.04^{\mathrm{b}}$ & $100.15 \pm 1.18$ & $11.13 \pm 0.03^{\mathrm{b}}$ & $99.48 \pm 0.67$ \\
GIPR alone & $11.27 \pm 0.04$ & $98.71 \pm 1.09$ & $11.34 \pm 0.04$ & $98.64 \pm 1.00$ & $10.00 \pm 0.03$ & $100.45 \pm 0.94$ \\
GIPR+SV1 & $11.27 \pm 0.04$ & $99.11 \pm 1.04$ & $11.26 \pm 0.04$ & $98.61 \pm 1.17$ & $9.81 \pm 0.03^{\mathrm{d}}$ & $100.40 \pm 1.12$ \\
GIPR+SV2 & $11.31 \pm 0.05$ & $99.06 \pm 1.28$ & $11.31 \pm 0.04$ & $99.01 \pm 1.09$ & $9.84 \pm 0.03^{\mathrm{c}}$ & $100.83 \pm 1.25$ \\
GIPR+SV3 & $11.38 \pm 0.04$ & $99.07 \pm 0.98$ & $11.42 \pm 0.04$ & $98.72 \pm 0.93$ & $9.96 \pm 0.03$ & $100.32 \pm 0.84$ \\
GIPR+SV4 & $10.66 \pm 0.04^{\mathrm{e}}$ & $98.54 \pm 1.27$ & $10.81 \pm 0.04^{\mathrm{e}}$ & $97.94 \pm 1.12$ & $9.70 \pm 0.02^{\mathrm{e}}$ & $100.72 \pm 0.82$ \\
\hline
\end{tabular}

614 cAMP accumulation was performed in HEK293T cells. Dose-response curves were 615 analyzed using a three-parameter logistic equation to obtain $\mathrm{pEC}_{50}$ and $\mathrm{E}_{\max }$. Data 616 shown are means \pm SEM of at least three independent experiments. One-way ANOVA 617 was used to determine statistical difference. ${ }^{\mathrm{a}}, \mathrm{P}<0.05,{ }^{\mathrm{b}}, \mathrm{P}<0.0001$ compared with 618 GIPR. ${ }^{\mathrm{c}}, \mathrm{P}<0.01,{ }^{\mathrm{d}}, \mathrm{P}<0.001$ and $^{\mathrm{e}}, \mathrm{P}<0.0001$ compared with GIPR alone. 